\title{
La construcción de la urbe y sus cuerpos
}

The construction of the city and the citizen's body

\begin{tabular}{c} 
JAIME MoRALES QUANT \\
\hline $\begin{array}{c}\text { Universidad de Cartagena. Cartagena, Colombia } \\
\text { jamoq22@yahoo.com }\end{array}$
\end{tabular}

\begin{abstract}
Como dijera Ángel Rama (1984) en una de sus obras más celebradas, la ciudad moderna no puede pensarse sin una red de construcciones simbólicas que la moldean, la controlan y constituyen. En esta línea de pensamiento cabe aludir a dos ensayos que reflexionan sobre la urbe desde los entramados de la escritura ordenadora, disciplinante. Ellos son "Decorar la ciudad: crónica y experiencia urbana” de Julio Ramos (2003) y "Modernización y disciplinamiento. La formación del ciudadano: el espacio privado y público", de Beatriz González Stephan (1995). Aunque los textos presen$\tan$ formas de abordaje diferenciables, pueden converger en, al menos, tres aspectos:
\end{abstract}

a) Revelan una serie de relaciones entre la producción escrita (la crónica y los manuales de buenas maneras) y la constitución de la experiencia urbana moderna; b) trazan nexos relevantes entre los discursos y los poderes (económico y político); c) y advierten los límites de las representaciones realizadas por estas escrituras. Palabras más, palabras menos, los ensayos mencionados ponen de plano cómo dos géneros menores sirven para erigir concepciones sobre la ciudad decimonónica del continente americano, construyendo/reproduciendo imágenes de unidad y coherencia; delineando el tipo de ciudadano correcto, etc. En este sentido, son leídos como propuestas ideológicas que forman y consolidan subjetividades aptas para habitar el escenario moderno naciente; participan -junto a otros aparatos de poder- en el proceso de forjar cómo sentir, habitar, soñar, actuar, relacionarse en/con determinada ciudad. Pero también es de anotar que ambos autores están interesados en revelar las limitaciones, enmascaramientos y obliteraciones que realizan 
las crónicas y el manual, respectivamente: si bien estos discursos tratan de eludir, ocultar o suavizar algunos semblantes de la urbe y sus habitantes, ésta sigue siendo un todo complejo en el que no cesan las tensiones, el caos, lo contradictorio, la inasible heterogeneidad.

\section{LA CRÓNICA QUE INSTAURA}

El ensayo de Julio Ramos se caracteriza por una lucidez que repara en paradojas y matices. El autor aborda la crónica para analizar cómo su flexibilidad formal le permite "convertirse en un archivo de los peligros de la nueva experiencia urbana, (en) una puesta en orden de la cotidianidad aún inclasificada por los "saberes" instituidos" (2003: 113). Pero también reconoce que este género "menor" hace parte de una industria cultural que busca difundir imágenes y conductas afines al espíritu del capitalismo. Ramos se ubica en la última década del siglo XIX, cuando el periódico ha creado una serie de exigencias para el cronista: ser un guía en el mercado de lujo y bienes culturales "contribuyendo a cristalizar una retórica del consumo y la publicidad" (113). En este sentido, la crónica sirve para representar-construir a la ciudad como un espacio apto para el deleite de las mercancías. Un trabajo que estaría a cargo de varios escritores suscritos al modernismo, entre los cuales se puede destacar a cierto Rubén Darío y su idea de felicidad capitalista, tecnológica, y al tiempo estética (114); o el proyecto de un Gómez Carrillo que pensaba en una literatura aplicada a la moda y en la erótica de los objetos mercantiles. Por más que resulte obvio, cabe recordar que estos escritores tenían en mente un destinatario particular, no menos relevante en la edificación de los imaginarios modernos: el sujeto "burgués, refinado, doméstico" (114), deseante de acumulación material y monetaria.

Ahora bien, en la medida en que la ciudad es el lugar de la fragmentación, la crisis de las tradiciones y la comunidad, una de las tareas culturales más urgentes consiste en reorganizar la extrañeza que suscita el devenir moderno; en proponer imágenes que compensen tales quebraduras. La crónica debe intervenir en la resolución de tal problema y aportar una narratividad que permita empalmar las temporalidades, es decir, resarcir la discontinuidad entre el pasado y el presente. Una de las operaciones para lograrlo es la representación de la urbe como un espacio armónico en donde el caos social yace atenuado o ausente. Otra implica rastrear en los demás sujetos las "señas de una identidad compartida". Esto requiere de un cronista paseante, un flaneur que persigue y construye las marcas del orden, la continuidad y 
familiaridad en sus caminatas. Tras el uso de dispositivos como el chisme, el voyerismo, la transcripción de la oralidad de los que hablan en la calle, el cronista encuentra las huellas de una colectividad posible. Sin embargo, la reconstrucción de lazos de identidad dista de ser colectiva en el sentido más amplio de la palabra, puesto que más bien se trata de forjar-afianzar una imagen en la cual se vienen a reconocer los burgueses como familia.

Así las cosas, el texto de Ramos va ofreciendo las piezas que permiten contemplar las relaciones entre crónicas y poderes: como advertíamos más arriba, las imágenes de belleza y unidad que se fabrican desde la escritura permanecen vinculadas con los intereses de una industria cultural que propaga una disposición consumista, pero también están conectadas con proyectos políticos que preparan la vigorización de una clase burguesa.

Por lo anterior, podemos decir que el discurso de la crónica revela sus límites, sus polarizaciones y trampas. Las preguntas son: ¿Quiénes quedan afuera de esta familia?, ¿qué clase de sujetos?, ¿de qué manera son representados los Otros? La crónica decora la multiplicidad social de lo urbano cuando aborda a dos de sus figuras problemáticas: la clase obrera (amenaza de la burguesía y el sistema económico vigente) y a la prostituta (amenaza a la familia) (Ramos, 2003). Una de las estrategias que usa consiste en representar a estos sujetos con ternura, o en clasificarlos tras la fijeza del estereotipo. Así, hace posible que la ciudad desigual, pobre y lumpen sea disimulada por una mirada estetizante que la embellece, la ordena, la controla. Para decirlo con Ramos: "la estilización de la crónica transforma los signos amenazantes del 'progreso' y la modernidad en un espectáculo pintoresco, estetizado" (114).

Pero lo cierto es que hay un espacio para el cronista disidente que, por una parte, instala la heterogeneidad problemática; por la otra, esgrime el cuestionamiento a las instituciones. Esta figura bien puede ejemplificarse con José Martí ${ }^{1}$, el cual se resiste a enmascarar la urbe, se aparta de los derredores de la industria cultural, y despliega, en contrapartida, una imagen crítica del desastre. Habrá que recordar que el autor cubano "registra la miseria, la explotación que las formas entonces más avanzadas de la modernidad (en los Estados Unidos) generaban” (Ramos, 2003: 140). Que su crónica aparece como el reverso de la modernista, pues "la miseria allí no es pintoresca ni dócil (...)" y especialmente, el otro aparece "indomesticado"

${ }^{1}$ De acuerdo con Ramos, la explicación de esta diferencia entre el autor cubano y otros modernistas tiene su respuesta no sólo en una experiencia personal, sino debido a "las luchas en el interior del campo intelectual; pugnas entre diferentes posiciones y conceptos literarios...supone una crítica de la incorporación de lo estético, como esfera autónoma, por la industria cultural" (2003: 142). 
(141). En efecto, Martí: “(...) no decora, no resuelve las tensiones de la ciudad: al contrario (...) parecería que la fragmentación del cuerpo del otro contamina con su violencia el espacio mismo del discurso, el lugar seguro del sujeto que a la vez reclama distancia" (141).

Por esto, es posible decir que la ciudad pasa por discursos disímiles que la tejen: se ordena y se re-ordena de manera incesante. De modo que una de las lecciones que proporciona el texto de Julio Ramos es la de postular a la escritura misma como escenario que ofrece múltiples posibilidades de control e impugnación; diferentes itinerarios en la re-configuración de la experiencia moderna y urbana.

\section{EN BUSCA DEL CUERPO CIVILIZADO}

En términos generales, el texto de González Stephan (1995) habla de otro género menor (no literario), "los manuales de urbanidad", pero se concentra específicamente en el famoso Manual de urbanidad y buenas maneras (1854) de Manuel Antonio Carreño. El estudio recorre parte de los procesos socioculturales de Venezuela durante el siglo XIX, privilegiando los efectos que tiene la escritura sobre la formación del ciudadano civilizado. Al igual que Ramos, reflexiona sobre la fuerza de una escritura que delinea-delimita a los sujetos de la urbe, mediada por intereses de clase y determinados proyectos de nación. De acuerdo con la autora:

(...) la escritura del Manual funciona dentro del campo institucional que despliega la autoridad del libro -en su relación concomitante entre escritura y poder-como la regulación/ reglamentación de nuevas jerarquías, la sujeción cuidadosa y controlada de las subjetividades y deseos, el etiquetamiento de los impulsos espontáneos y culturales (...) (González Stephan, 1995: 434).

Hay que señalar que en el período referido existe un público que anhela seguir cierta idea de "progreso" importada desde Europa; instalarse en las filas de una modernidad que prometía aventuras, reconocimiento, acumulación material, etc. (Berman, 1991). Los manuales, y en especial el de Carreño, funcionan justamente como los dispositivos mediante los cuales se forman sujetos con miras al éxito social, político y económico. Tal como dice González Stephan:

(...) entre la vasta agenda que implicaba el proyecto de construcción de las 
nuevas naciones, uno de los aspectos no menos decisivos era la modelación de los hombres y mujeres capaces de funcionar en concordancia con el nuevo estilo urbano de la vida (1995: 432).

Hay que decir que la escritura del Manual funda/difunde un orden con el que se busca consolidar a un nuevo protagonista de la modernización; sirve para asimilar y promover una cotidianidad capitalista, pues "modeliza en el nivel de las construcciones de individualidades, la percepción del cuerpo y las relaciones interpersonales, los nuevos valores del individualismo económico" (González Stephan, 1995: 440). En este sentido, uno de los aspectos que más destaca la ensayista venezolana es el disciplinamiento corporal que ejerce el Manual sobre los que habitan la ciudad, y el beneficio que acarrea esta regulación a la hora de obtener ascenso socioeconómico: se trata de una sociedad “(...) para la cual el que tenía dinero y sobre todo aprendía 'maneras' tenía garantizado el éxito social” (438). Cabe preguntarse, desde luego, ¿quién es la figura social que debe leer este discurso? Si como veíamos antes, la crónica construye y educa a un público, al tiempo que diseña "un afuera" donde habitan otros sujetos y problemáticas, el manual también posee, por un lado, un destinatario que corresponde a la emergente clase burguesa. En palabras de González Stephan: ese "nosotros" son (...) los nuevos dueños de casas ubicadas en centros urbanos (...) con varios ambientes, salones, comedores, dormitorios, jardines, habitaciones para no pocos sirvientes" (439). Por el otro, concreta una posición "equidistante" respecto a los sirvientes y a personas "que están en una situación de poder" (440). Ni "el habitante del campo (...) ni las capas medias bajas, los esclavos, como tampoco la oligarquía señorial" (442). Todo ellos configurando "la otredad" que habita en los márgenes del Manual; señalando su límite.

Por lo demás, una tesis adicional que explica la conveniencia de dicho texto para la élite burguesa reside en que suministra una serie de disposiciones morales capaces de generar simpatía en la clase señorial que gobierna en ese momento:

En la medida en que el nuevo sujeto burgués vio sus posibilidades materiales de ascenso quiso adaptar las maneras exteriores de las clases patricias, clases que tenían como natural los hábitos de corte asimilados por tradición. (Se requiere) construir un ciudadano ideal y obediente en un Estado autoritario y hegemónico como lo fue particularmente el guzmanato (1870-1888) y posteriormente el gomecismo (1909-1935)" (González Stephan, 1995: 447). 
Por fortuna, el ensayo de González Stephan no se detiene en una unilateralidad reduccionista de las relaciones, sino que deja ver el juego de utilidades recíprocas y complejas entre ambos actores sociales: el discurso de Carreño es útil no sólo para los burgueses en ascenso, también para el gobierno del momento, puesto que "el Estado en su proyecto de la formación nacional necesita de estos ciudadanos, dóciles, reprimidos, prisioneros bajo las máscaras de la urbanidad de las buenas maneras" (447).

En cierta medida, y según González Stephan, lo que busca este manual es una diferenciación compleja: que el sujeto trate de apartarse de la barbarie "encarnada" en los sujetos subalternos, mediante una operación paradójica: destruyendo al bárbaro que se llevaba dentro, al Otro interno. Se trata de un discurso que quiere regular los cuerpos, impartiendo instrucciones que develan el gran "régimen de prohibición" que lo compone: cómo, cuándo y dónde "estornudar, bostezar, sonarse la nariz, estirarse, reírse, roncar, aplaudir, escupir... tocarse partes del cuerpo o tocar a otro, mirar a otros, mover las manos, beber, preguntar, fumar, discutir (...)" (445); también cabe rememorar: "la variedad de tenedores, cuchillos, cucharas copas, vasos y servilletas (...) el complejísimo código de las presentaciones especiales: la oportunidad de las visitas, su duración" o "el modo de conducirnos en la mesa (que) ofrece 53 reglas a seguir" (439).

Tras el cúmulo de prohibiciones expuestas, queda claro que el Manual irrumpe en el ámbito de lo público, pero también en el privado. Ciertamente, el espacio doméstico no es el lugar de la liberación o de los goces secretos, sino el de una estricta autovigilancia: "es el primer espacio donde el sujeto aprende su encorsetamiento" (448). De aquí se deriva, por una parte, un tipo de individuo "(...) que calla, que no discute (...) desconoce su cuerpo y el cuerpo del otro, aprisiona su yo, escuda sus afectos" (447). Por la otra, se clausura la multiplicidad social, toda vez que el texto construye una imagen de la ciudad donde no tienen cabida otras formas de pensar, actuar, vestirse; donde no hay lugar legítimo para otra clase de sujetos. En este orden de cosas, es un discurso que puede pensarse aludiendo a los gobiernos autoritarios de la época, y también más allá: como signo de la modernidad y su propensión al control. Con notable herencia Foucaultiana, González Stephan conduce a pensar en la relación directamente proporcional entre la edad moderna y el aumento progresivo de dispositivos de vigilancia y ordenamiento mediante discursos. En la notable y abrumadora "contigüidad entre civilización/ progreso/ modernización y sacrificio/ apariencia / dominación" (447). 


\section{CODA}

Ambos ensayos permiten comprender el diálogo entre las prácticas y los discursos; los vínculos entre identidad (nacional, individual, estética) y escritura. La existencia de las crónicas y los manuales en tanto artefactos escritos, ratificaría que la lectura y la escritura se convierten en dos "reguladores del complejo simbólico cultural" (González Stephan, 1995: 437); unos aprendizajes que funcionan como condición para entrar a la "civilización" y a la modernidad (1995). No obstante, bajo la figura de Martí, también aparece la palabra revestida de su fuerza crítica: increpando las representaciones auspiciadas por la industria cultural, desarticulando las "tramas simbólicas" (Nieves, 1997). Teniendo en cuenta estas dimensiones, las propuestas de Ramos y González conducen a una concepción de la urbe como espacio de semiosis (1997): el lugar de un permanente flujo sígnico. Y para terminar, no es descabellado proponer que la ciudad funciona como una máquina que diseña afueras y adentros, resignifica los espacios físicos, y cataloga a unos y a otros seres humanos. En este sentido, se constituye en cierto lugar de la carencia: es el silencio de los que podrían hablar, pero a quienes se les niega la voz; la ausencia de aquellos que podrían aparecer, pero a quienes se les resta presencia.

\section{REFERENCIAS}

Berman, Marshall. 1991. Todo lo sólido se desvanece en el aire. Madrid: Siglo XXI.

González Stephan, Beatriz. 1995. "Modernización y disciplinamiento. La formación del ciudadano: el espacio privado y público". En Esplendores y miserias del siglo XIX. Caracas, Monte Ávila: Universidad Simón Bolívar.

Rama, Ángel. 1984. La ciudad letrada. Hanover: Ed. Del norte.

Ramos, Julio. 2003. "Decorar la ciudad: crónica y experiencia urbana". En Desencuentros de la Modernidad en América Latina. Santiago de Chile: Editorial Cuarto Propio.

Nieves Oviedo, Jorge. 1997. "Acerca de la competencia sociocultural", en Colombia. Historia y Cultura 5, pp. 287-328. 